\title{
PROSES PEMBENTUKAN AQIDAH DAN AKHLAK PADA SISWA SEKOLAH DASAR DI KOTA JAYAPURA
}

\author{
Didik Efendi \\ Prodi Pendidikan Guru Madrasah Ibtidaiyah \\ Institut Agama Islam Negeri Fattahul Muluk \\ Jl. Merah Putih, Buper Waena Distrik Heram, Jayapura, Indonesia \\ E-mail: didik.kotjap@gmail.com \\ Website: https://jurnal.uin-antasari.ac.id/index.php/adzka \\ Received: Mei 2019; Accepted: Juni 2019; Published: Juni 2019
}

\begin{abstract}
This research aimed to capture the process of an establishment of aqeedah and morality as well as its causative factors that influence the students at Elementary Schools in Jayapura City. This qualitative research used a case-study design. The research was conducted at Sekolah Dasar Islam Terpadu (SDIT) Permata Hati in Jayapura City. In order to collect the data, the researcher did observation, interview, and documentation. The result of this research showed that the process of the students' aqeedah and morality establishment at SDIT Permata Hati through four stages. 1) Receiving, in this stage teachers provided knowledge about the values of aqeedah and morality that should be possesses by the students. 2) Responding, in this stage the students begun to actively responding to what the teachers taught. 3) Acting, in this stage the students were given opportunity to actualize the values of aqeedah and morality in their daily activities. 4) Being, in this stage the students must be formed their aqeedah and morality and being their behaviour. Whereas the factors influenced the establishment of the students' aqeedah and morality were the role of the teachers and parents.
\end{abstract}

Key words: establishment; aqeedah; morals; students.

\begin{abstract}
ABSTRAK
Penelitian ini bertujuan untuk memperoleh gambaran proses terbentuknya aqidah dan akhlak serta faktor yang mempengaruhi keberhasilan dalam proses pembentukan aqidah dan akhlak pada siswa Sekolah Dasar (SD) di kota Jayapura. Penelitian kualitatif ini menggunakan desain studi kasus. Penelitian ini dilakukan di Sekolah Dasar Islam Terpadu (SDIT) Permata Hati kota Jayapura. Pengumpulan data dalam penelitian ini dilakukan melalui observasi, interview, dan dokumentasi. Hasil penelitian menunjukkan bahwa proses terbentuknya aqidah dan akhlak pada siswa SDIT Permata Hati melalui empat tahapan yakni (1) Receiving (menerima). Pada tahap ini guru memberikan pemahaman/ pegetahuan tentang nilai-nilai aqidah dan akhlak yang harus dimiliki, (2) Responding (menanggapi). Tahap ini siswa sudah mulai aktif dalam menanggapi apa yang diberikan oleh guru yang terkait dengan aqidah dan akhlak. (3) Acting (bertindak). Pada tahap ini siswa diberi kesempatan untuk mengaktualisasikan nilai-nilai aqidah dan akhlak yang sudah diresponnya dalam kehidupanya sehari-hari. (4) Being (menjadi seperti yang diketahui). Pada tahap ini siswa seharusnya sudah terbentuk aqidah dan akhlaknya atau bisa dikatakan sudah menjadi kebiasan (being). Sedangkan faktor pendukung keberhasilan pembentukan aqidah dan akhlak pada siswa SDIT Permati Hati diantaranya adalah peran guru dan orang tua.
\end{abstract}

Kata kunci: pembentukan; aqidah; akhlak; siswa. 


\section{PENDAHULUAN}

Sebagai Negara yang mayoritas beragama Islam, sudah sewajarnya menerapkan nilainilai agama Islam dalam kehidupan sehari-harinya. Namun fakta membuktikan masih banyak orang Islam yang tidak sesuai dengan nilai-nilai agama Islam yang dianutnya. Pendidikan agama Islam mempunyai peran yang sangat strategis untuk menanamkan nilai-nilai yang terkandung dalam ajaran Islam kepada pemeluknya. Salah satu nilai-nilai ajaran Islam yang perlu ditanamkan kepada seseorang sejak kecil adalah aqidah dan akhlak. Aqidah memiliki pengaruh yang sangat signifikan terhadap akhlak seseorang. Sehingga dapat dikatakan apabila seseorang memiliki aqidah yang kuat, bisa dipastikan akhlaknya akan terpuji/baik, tetapi sebaliknya apabila seseorang lemah aqidahnya, maka akhlaknya pun juga kurang baik (tercela). Sebagaimana hadits Rasulullah yang artinya orang mukmin yang sempurna imannya ialah yang terbaik akhlaknya. (H.R at-Tirmidzi:1082 ).

Aqidah merupakan perbuatan hati, yakni menyakini dan membenarkan terhadap sesuatu tanpa ada keraguan sedikitpun. Aqidah mampu menciptakan kesadaran diri manusia untuk berpegang teguh kepada nilai-nilai dan norma akhlak yang mulia. Sebagaimana yang diungkapkan oleh Hidayat (2015:202) akhlak harus berpedoman pada aqidah yang kokoh. Aqidah tidak cukup hanya disimpan dalam hati, akan tetapi harus dipraktekkan dalam kehidupan sehari-hari Sementara akhlak merupakan bagian yang tidak bisa dipisahkan dari aqidah Islam. Akhlak bagaikan mata rantai dari sebuah aqidah yang kuat. Akhlak tanpa aqidah akan terasa hampa, sedangkan aqidah tanpa akhlak bagaikan bangunan yang mewah tetapi pondasinya tidak kuat. Jadi aqidah yang kuat akan mencerminkan akhlak atau kepribadian seseorang.

Salah satu faktor yang mempengaruhi aqidah dan akhlak anak adalah lingkungan. Lingkungan terbagi menjadi tiga, yakni lingkungan keluarga, sekolah dan tempat bermainya anak (lingkungan masyarakat). Lingkungan yang sangat mempengauhi aqidah dan akhlak anak adalah lingkungan dimana mereka bermain dan bergaul dengan teman sebayanya. Di lingkungan inilah anak-anak akan mendapatkan pengalaman-pengalaman baru dalam hidupnya. Apabila anak berada di lingkungan yang kurang kondusif seperti lingkungan yang didalamnya terbiasa dengan hal-hal yang kurang baik, maka bisa dipastikan kepribadian anak seperti itu juga, karena sifat anak yang suka meniru hal-hal yang disenanginya.

Kota Jayapura adalah kota yang bisa dikatakan Indonesia mini, dimana Kota Jayapura terdapat berbagai suku, bahasa, agama, budaya dan perbedaan-perbedaan lainnya. Secara garis besar suku yang mendiami di kota Jayapura adalah suku asli warga Jayapura, suku Jawa, suku Bugis, suku Dayak, suku Hamadi, suku Wamena. Selain suku di kota Jayapura juga terdapat beberapa agama, yakni agama Islam, Kristen Protestan, Kristen Katolik, Budha, dan Konghucu. Setiap suku dan agama mempunyai budaya dan ajaran masing-masing. Dengan banyaknya perbedaan tersebut, maka akan banyak faktor yang akan mempengaruhi aqidah dan akhlak seorang anak. Kota Jayapura merupakan salah satu tempat pelarian yang aman bagi setiap anak-anak korban Narkotikan, Psikotropika dan Zat-zat adiktif lainnya (NARKOBA) hingga para Pekerja Sek Komersial (PSK) anak dari berbagai daerah (Papua, 2015).

Selain itu Kota Jayapura juga ditemukan anak-anak yang menghirup lem aibon (biasa orang Jayapura mengenal dengan sebutan anak-anak aibon) secara bergerombol dan bergantian. Hal ini dibenarkan oleh Lembaga Profesi Pekerja Sosial (LP2S) Papua, serta Relawan Komunitas Anak Ceria (KOMa-RIA) Papua. Mereka turun ke beberapa lokasi tempat dan menemukan anak-anak Penghirup lem aibon dan PSK anak berada di jalan Garuda, Abepura Kota Jayapura. Pelecehan seksual juga terjadi di Kota Jayapura, sebagai contoh disampaikan Sawaki, bahwa di Kota Jayapura ada kasus anak berumur sembilan tahun berbuat asusila terhadap anak berumur lima tahun (Okezone, 2015). 
Lingkungan Kota Jayapura menjadi lingkungan yang sangat rawan bagi orang yang kurang kuat aqidahnya. Semakin banyaknya suku, budaya dan agama, maka semakin banyak pula karakteristik, budaya atau kebiasaan-kebiasaan yang beragam. Sebagai contoh budaya atau kebiasaan-kebiasaan masyarakat Kota Jayapura dalam kesehariannya adalah minumminiman keras dalam berbagai kegiatan, berpakaian yang tidak sesuai dengan ajaran Islam (tidak menutup aurat), dalam hal berbicara banyak terdengar bahasa-bahasa yang kotor dan tidak baik serta pergaulanya mereka cenderung mengarah pergaulan bebas. Selain itu, dengan masyarakatnya yang di dominasi umat Kristiani, maka budaya umat Kristen menjadi budaya di Kota Jayapura. Apabila aqidah anak-anak tidak kuat, maka aqidah mereka akan luntur bahkan hilang dan mengikuti kebiasaan atau budaya masyarakat setempat. Kebudayaan setiap kelompok mayarakat (bangsa, ras atau suku bangsa) memiliki tradisi, adat atau kebudayaan yang khas. Tradisi atau kebudayaan suatu masyarakat memberikan pengaruh terhadap kepribadian setiap anggotanya, baik yang menyangkut cara berpikir, cara bersikap dan cara bertingkah laku.

Aqidah memberikan peranan penting bagi kehidupan seseorang, tanpa aqidah yang benar, seseorang akan terjerumus dalam keraguan dan berbagai prasangka yang lamakelamaan akan menutup pandangannya dan menjauhkan diri dari kebahagiaan. Selain itu tanpa aqidah yang kuat, seseorang akan mudah dipengaruhi oleh berbagai informasi/ kelompok yang ingin menjerumuskannya. Menurut Alim (2006: 130-131) fungsi dan peranan aqidah bagi kehidupan manusia di antaranya; (1) menuntun dan mengemban dasar ketuhanan yang dimiliki manusia sejak lahir, (2) memberikan ketenangan dan ketentraman jiwa serta; (3) memberikan pedoman hidup yang pasti. Aqidah juga memiliki pengaruh yang sangat signifikan terhadap akhlak seseorang, sehingga dapat dikatakan apabila seseorang memiliki aqidah yang kuat, bisa dipastikan akhlaknya akan terpuji/baik, tetapi sebaliknya apabila seseorang lemah aqidahnya, maka akhlaknya pun juga kurang baik (tercela).

Berdasarkan paparan diatas maka penetitian ini bertujuan untuk mengetahui gambaran proses terbentukannya aqidah dan akhlak serta mengetahui faktor-faktor keberhasilan dalam pembentukan aqidah dan akhlak pada siswa Sekolah Dasar (SD) di SDIT Permata Hati Kota Jayapura.

\section{Aqidah dan Akhlak}

Aqidah menurut bahasa Arab (etimologi) berasal dari kata al-aqdu yang berarti ikatan, At-tautsiiqu yang artinya kepercayaan atau keyakinan yang kuat, al-ihkaamu yang artinya mengokohkah (menetapkan) dan ar-rabthu buquwwah yang arti mengikat dengan kuat (Jawas, 2008:27). Sedangkan menurut istilah (termologi), aqidah adalah iman yang teguh dan pasti, yang tidak ada keraguan sedikit pun bagi orang yang menyakininya (Jawas, 2008:27). Adapun beberapa nilai-nilai dasar dari aqidah yang perlu dipahami siswa sekolah dasar meliputi: (1) kalimat thayyibah sebagai materi pembiasaan, yang meliputi: Laa ilaaha illallah, basmalah, alhamdulillah, subhanallah, Allaahu Akbar, ta'awudz, maasya Allah, assalamu'alaikum, salawat, tarji' laa haula walaa quwwata illa billah dan istigrar; (2) mengenal Al-Asma' al-Husna; (3) memahami perintah shalat dan mengerjakan shalat; (4) menyakini rukun iman (iman kepada Allah, Malaikat-malaikat-Nya, Kitab-kitab-Nya, RasulRasul-Nya dan Hari Akhir serta Qadha dan Qadar Allah (PMA no. 912 tahun 2013).

Kata "akhlak"secara etimologi berasal dari kata "khalaqa" yang berarti mencipta, membuat atau menjadikan. Kata "akhlak" adalah kata yang berbentuk mufrad, jamaknya adalah "khuluqun" yang berarti peranggai, tabiat, adat atau "khalqun" yang berarti kejadian, buatan, ciptaan. Jadi "akhlak" adalah perangai, adab, tabiat, atau sistem perilaku yang dibuat oleh manusia (Ali, 2017:29). Dalam pengertian sehari-hari akhlak umumnya disamakan artinya dengan budi pekerti, kesusilaan, sopan santun dalam bahasa Indonesia dan tidak berbeda pula dengan arti moral, ethic dalam bahasa Inggris (Mansur, 2005:201). Akhlak 
secara termologi (istilah) memiliki beberapa pengertian, sebagaimana disebutkan oleh beberapa tokoh, pertama Al-Ghazali yang dikutip oleh Nur hidayat dalam bukunya aqidah akhlak dan pembelajaranya, Al-Ghazali mengemukakan bahwa akhlak adalah suatu sifat yang tertanam dalam jiwa dari padanya timbul perbuatan-perbuatan dengan mudah dan tanpa memerlukan pemikiran dan pertimbangan (Hidayat, 2015:137). Adapun nilai-nilai akhlak yang harus miliki bagi siswa sekolah dasar diantaranya adalah (1) memiliki akhlakul karimah yang meliputi: dislipin, hidup bersih, ramah, sopan-santun, syukur nikmat, hidup sederhana, rendah hati, jujur, rajin, percaya diri, kasih sayang, taat, rukun, tolong menolong, hormat dan patuh, amanah dan lain sebaginya; (2) menghindari akhlak tercela yang meliputi: berkata kotor, hidup kotor, bohong, sombong, malas, durhaka, khianat, iri, dengki dan lain sebagainya; (3) aspek adab Islami yang meliputi adab terhadap diri sendiri (adab makan, dan minum, mandi, tidur, buang air besar/ kecil, berbicara dan lain sebagainya (PMA no. 912 tahun 2013).

\section{Karakteristik Siswa Sekolah Dasar (SD)}

Di Indonesia, kisaran usia sekolah dasar berada diantara umur 6 atau 7 tahun sampai 12 tahun dan memiliki fisik lebih kuat, mempunyai sifat individual, aktif serta tidak bergantung dengan orang tua. Masa usia sekolah dasar ini dapat kita rinci menjadi dua fase, yakni masa kelas-kelas rendah berkisar umur 6/7 sampai 9 tahun dan masa kelas-kelas atas berkisar umur 9/10 sampai 13 tahun. Karakteristik pada masa usia sekolah dasar biasanya identik dengan sebutan-sebutan untuk menandai kecenderungan umum yang terjadi pada masa ini, contohnya usia yang menyulitkan, usia yang tidak rapi, usia bertengkar, usia berkelompok, usia penyesuaian diri, usia kreatif dan kritis, usia bermain dan lain sebagainya (Nazarudin, 2007:46).

Menurut Havighurs dalam (Desmita, 2010:35-36), menyatakan bahwa tugas perkembangan siswa Sekolah Dasar (SD) meliputi:

1. Menguasai keterampilan fisik yang diperlukan dalam permainan dan aktifitas fisik

2. Membina hidup sehat

3. Belajar bergaul dan bekerja dalam kelompok

4. Belajar menjalankan peranan sosial sesuai dengan jenis kelamin

5. Belajar membaca, menulis dan berhitung agar mampu berpartisipasi dalam masyarakat.

6. Memperoleh sejumlah konsep yang diperlukan untuk berpikir efektif

7. Mengembangkan kata hati, moral dan nilai-nilai

8. Mencapai kemandirian pribadi.

Perkembangan pada siswa sekolah dasar dapat dilihat dari berbagai aspek, diantaranya adalah Pertama, Perkembangan Intelektual. Pada aspek ini, siswa sudah dapat mereaksi rasangan intelektual atau melaksanaan tugas-tugas belajar yang menuntut kemampuan intelektual atau kemampuan kognitif. Kemampuan intelektual pada masa ini sudah cukup untuk menjadi dasar diberikannya berbagai kecakapan yang dapat mengembangkan pola pikir atau daya nalar. Untuk itu dalam sekolah, guru harus dapat mengembangkan kreatifitas anak. Kedua, perkembangan bahasa. Bahasa adalah sarana berkomunitasi dengan orang lain. Pada masa ini merupakan masa berkembang pesatnya kemampuan mengenal dan menguasai perbendaharaan kata (vocabulary) (Yusuf \& Sugandhi, 2011:62). Ketiga, perkembangan sosial. Perkembangan sosial adalah pencapaian kematangan dalam hubungan atau reaksi social (Yusuf \& Sugandhi, 2011:65). Dapat diartikan juga sebagai proses untuk menyesuaikan diri dengan norma-norma kelompok, tradisi dan moral agama. Perkembangan sosial pada siswa SD dapat kita lihat dengan adanya perluasan hubungan, baik hubungan dengan anggota keluarga, teman sebaya, lingkungan, sehingga ruang hubungan sosialnya semakin luas. Pada usia ini, anak mulai memiliki kesanggupan diri dari sikap berpusat kepada diri sendiri (egosentris), kepada sikap kerja sama (kooperatif) atau sosiosentris (mau memperhatikan 
kepentingan orang lain) (Yusuf \& Sugandhi, 2011:66). Keempat, perkembangan moral. Selain mengalami perkembangan intelektual, bahasa, dan sosial, siswa sekolah dasar juga mengalami perkembangan moral. Perkembangan moral dalam hal ini adalah pembentukan dan pematangan pemahaman mengenai benar dan salah di kalangan anak-anak sejalan dengan perkembangan kognitif mereka (Syah, 2014:50).

\section{Proses Pembentukan Aqidah dan Akhlak pada Siswa Sekolah Dasar (SD)}

Aqidah merupakan hal pertama yang harus dikenalkan kepada anak sejak usia dini, hal tersebut dilakukan agar supaya seorang anak dapat mengenal agamanya sejak anak kecil. Aqidah merupakan ceriman dari akhlak seseorang, apabila aqidah seseorang baik, maka bisa dipastikan akhlak seseorang baik pula. Untuk itu, Penanaman nilai-nilai yang terkandung dalam aqidah dan akhlak harus diberikan anak sejak dini, agar aqidah dan akhlak mereka terbentuk. Sebagai individu yang berkembang, anak memiliki sifat yang suka meniru tanpa mempertimbangkan baik atau buruk. Hal ini didorong oleh rasa ingin tahu dan mencoba sesuatu yang diminati yang kadang muncul secara spontan. Anak akan melihat dan meniru apa yang ada disekitarnya bahkan apabila hal itu sangat melekat pada diri anak akan tersimpan dalam memori yang panjang (Long Term Memory). Apabila dalam LTM tersimpal hal-hal yang baik maka akan menghasilkan hal-hal yang baik pula, tetapi apabila yang tesimpan adalah hal-hal yang buruk maka akan menghasilkan hal-hal yang buruk pula.

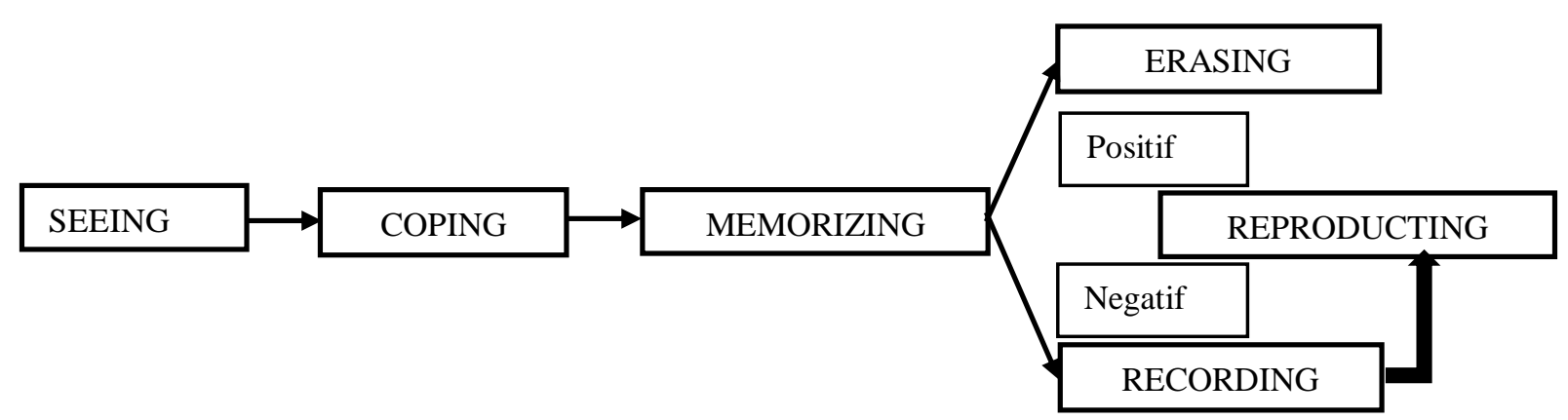

Gambar. 1 Tahap Pembentukan

Gambar tersebut menjelaskan bahwa anak (siswa) apabila akan melakukan sesuatu, selalu diawali dengan proses melihat, mengamati, meniru, mengingat, menyimpan kemudian akan mengeluarkannya kembali menjadi perilaku sesuai ingatan yang tersipan dalam otaknya. Menurut Krathwohl dalam (Lubis \& Zubaedi, 2011:19-21), mengungkapkan bahwa proses pembentukan nilai-nilai pada anak dikelompokkan menjadi 5 tahap, yakni:

1. Tahap receiving (menyimak)

Pada tahap ini seseorang secara aktif dan sensitif menerima stimulus dan menghadapi fenimena-fenomena, sedia menerima secara aktif dan selektif dalam memilih fenomena. Pada tahap ini nilai belum terbentuk melainkan baru menerima dan mencari nilai-nilai untuk dipilih mana yang paing menarik baginya.

2. Tahap Responding (menanggapi)

Pada tahap ini, seseorang sudah mulai bersedia menerima dan menggapai secara aktif dan stimulus dalam bentuk respons yang nyata. Dapam tahap ini ada tiga tingkatan yakni tahap compliance (manut), wilingness to respond (sedia menggapai) dan satisfaction in response (puas dalam menanggapi). Pada tahap ini seorang anak sudah mulai aktif menanggapi nilai-nilai yang berkembangan diluar dan meresponnya.

3. Tahap Valuing (memberikan nilai)

Pada tahap pertama dan kedua lebih banyak bersifat aktivitas fisik biologis dalam menerima dan menanggapi nilai, maka pada tahap ini anak sudah mampu menangkap stimulus itu atas dasar nilai-nilai yang terkandung di dalamnya dan mulai menyusun 
persepsi tentang objek. Dalam hal ini terdiri dari tiga tahap, yakni percaya terhadap nilai yang diterima, merasakan terikat dengan nilai yang dipercayai, dan memiliki keterkaitan batin (commitment) untuk memperjuangkan nilai-nilai yang diterimanya dan diyakininya.

4. Tahap mengorganisasikan nilai (organization)

Pada tahap ini, seseorang mulai mengatur sistem nilai yang diterimanya dari luar untuk diorganisasikan (ditata) dalam dirinya sehingga sistem nilai itu menjadi bagian yang tidak dipisahkan dalam dirinya. Pada tahap ini ada dua organisasi nilai, yakni mengkonsepsikan nilai dalam dirinya dan mengorganisasikan sistem nilai dalam dirinya yakni dengan cara hidup dan tata perilakunya sudah didasarkan atas nilai-nilai yang diyakininya.

5. Tahap karakterisasi nilai (characterization)

Pada tahap ini ditandai dengan ketidakpuasannya seseorang untuk mengorganisir sistem nilai yang dinyakini dalam hidupnya secara mapan, ajek, dan konsisten sehingga tidak dapat dipisahkan lagi dengan pribadinya. Pada tahap ini dikelompokkan dalam dua tahap, yakni tahap menerapkan sistem nilai dan tahap karakterisasi atau tahap mempribadikan sistem nilai.

Dalam pandangan Lickona dalam (Adisusilo, 2013:62), menyatakan bahwa pendidikan nilai/ moral yang menghasilkan karakter (akhlak), ada tiga komponen, yakni moral knowing (pengetahuan tentang moral), moral feeling (perasaan tentang mental) dan moral action (moral perbuatan).

a. Moral Knowing (pengetahuan tentang moral)

Menurut William Kilpatrick sebagaimana dikutip oleh Abdul Majid dan Dian Handayai menyebutkan bahwa salah satu faktor penyebab ketidakmampuan seorang berperilaku baik meskipun ia telah memiliki pengetahuan tentang kebaikan itu (Moral knowing) adalah karena ia tidak terlatih untuk melakukan kebaikan (moral doing). Dalam Moral knowing hal yang perlu diajarkan kepada siswa ada 6 hal, yakni Moral Awarenes ( kesadaran bermoral), kwoing moral values (mengetahui nilai-nilai bermoral), perspektitive taking ( penentuan sudut pandang), moral reasoning (logika moral), dicision making (keberanian menentukan sikap), self knowledge (pengenalan diri).

b. Moral Feeling (perasaan tentang mental)

Pendidikan nilai hanya sampai pada moral knowing tidak cukup, karena hanya sebatas memahami nilai-nilai tanpa melaksanakannya atau dapat diartikan anak/ siswa hanya pintar dalam konsepnya tetapi tidak melaksanakan apa yang dipelajari. Untuk itu harus dilanjutkan kepada tahap kedua, yaitu moral Feeling. Moral feeling merupakan perbuatan aspek emosi siswa untuk menjadi manusia yang berakhlak mulia. Penguatan ini berkaitan dengan bentuk-bentuk sikap yang harus dirasakan oleh siswa. Ada enam aspek emosi yang harus dimiliki siswa, yakni percaya diri (self esteem), kepekaan terhadap derita orang lain (emphaty), cinta kebenaran (loving the good), pengendalian diri (self control) dan kerendahan hati (humility).

c. Moral Action (moral perbuatan)

Tahap terakhir dalam pendidikan nilai adalah moral action. Moral Action adalah bagaimana membuat pengetahuan moral dapat diwujudkan menjadi tindakan nyata. Untuk memahami apa yang mendorong seseorang dapat berbuat baik dapat dilihat dari tiga aspek, yakni kompetensi (competence), keinginan (will) dan kebiasaan (habit).

Ketiga komponen tersebut menunjukkan pada tahapan pemahaman sampai pelaksanaan nilai/ moral (akhlak) dalam kehidupan sehari-hari. Ketiganya tidak serta merta terjadi dalam diri seorang anak (siswa), tetapi prosesual artinya tahapan ketiga hanya mungkin terjadi setelah mencapai tahapan kedua dan tahapan kedua hanya tercapai setelah tahapan pertama. 


\section{METODE PENELITIAN}

Berdasarkan permasalahan yang diteliti, jenis penelitian yang digunakan adalah penelitian dengan pendekatan kualitatif dengan jenis penelitian studi kasus. Penelitian kualitatif bertujuan untuk menggambarkan, meringkas berbagai kondisi, berbagai situasi, atau fenomena realitas sosial yang ada di masyarakat yang menjadi obyek penelitian dan berupaya menarik realitas itu ke permukaan sebagai suatu ciri, karakter, sifat, model, tanda atau gambaran tentang kondisi, situasi ataupun fenomena tertentu (Bungin, 2007:68). Sedangkan studi kasus (case study) adalah merupakan salah satu jenis penelitian kualitatif, dimana peneliti melakukan eksplorasi secara mendalam terhadap program, kejadian, proses, aktifitas terhadap satu atau lebih orang (Sugiono, 2013:24). Penelitian kualitatif dengan pendekatan studi kasus juga dapat diartikan penelitian yang difokuskan satu fenomena saja yang dipilih dan ingin dipahami secara mendalam dengan mengabaikan fenomena-fenomena yang lain (Sukmadinata, 2010;99).

Penelitian ini dilaksanakan di kota Jayapura provinsi Papua yaitu di Sekolah Dasar Islam Terpadu (SDIT) Permata Hati yang terletak di jalan raya Abepura No. 3A Entrop kota Jayapura provinsi Papua. Sumber data yang digunakan dalam penelitian ini terdiri dari dua bagian, yakni; sumber data primer dan sekunder. Data primer diperoleh langsung dari narasumber melalui wawancara, sedangkan data sekunder diperoleh dari selain data primer. Teknik pengumpulan data dalam penelitian ini menggunakan teknik pengumpulan data seperti berikut: (1) Observasi, (2) wawancara, (3) dokumentasi. Dalam teknik analisa data menggunakan analisa deskriptif kuantitatif, karena data yang diperoleh berupa kata-kata yang dinyatakan dalam narasi yang bersifat deskriptif mengenai peristiwa yang real dilapangan.

Adapun tahap-tahap analisis data menggunakan model Miles dan Huberman. (1) Pengumpulan data. Pengumpulan data adalah proses pengumpulan data mentah dimulai dengan memahmi fenomena yang diteliti, (2) reduksi data, yakni proses pemilihan, pemusatan perhatian pada penyederhanaan, pengabstrakan, transformasi data kasar yang muncul dari catatan-catatan lapangan. Data yang direduksi memberikan gambaran yang lebih jelas tentang pengamatan serta mempermudah peneliti untuk mencari kembali data yang diperoleh. (3) Display data, yakni sajian kalimat yang disusun secara logis dan sistematis. (4) penarikan kesimpulan dan verifikasi data, yakni upaya mencari kesimpulan dari masalah yang diteliti. Pada tahap ini kegiatan yang dilakukan adalah memberikan kesimpulan terhadap data-data hasil penafsiran. Verivikasi yakni menguji kebenaran, kekokohan dan mencocokan maknamakna yang muncul dari kata.

\section{HASIL PENELITIAN DAN PEMBAHASAN}

Pada umumnya usia siswa sekolah dasar di Indonesia, berkisar 6/7 tahun sampai 12/13 tahun. Siswa sekolah dasar mengalami empat perkembangan, salah satunya adalah perkembangan moral. Perkembangan moral dalam hal ini adalah pembentukan, pematangan dan pemahaman mengenai benar dan salah di kalangan anak-anak sejalan dengan perkembangan koqnitif mereka. Siswa sekolah dasar juga mempunyai sifat suka meniru tanpa adanya pertimbangan baik atau buruk. Hal ini disebabkan karena rasa ingin tahu dan ingin mencoba seorang siswa sekolah dasar sangat besar. Terbentuknya aqidah dan akhlak pada siswa tidak terlepas dari kegiatan siswa yang suka melihat, mendengar dan meniru apa yang ada disekitarnya. Apabila sesuatu yang dilihat dan didengar tersebut melekat atau sangat diukai siswa maka apa yang dilihat dan didengar akan tersimpan oleh anak di dalam memori yang panjang (Long Term Memory). Apabila di LTM itu tersimpan hal-hal yang baik maka akan menghasilkan hal-hal yang baik pula, tetapi sebaliknya apabila yang tersimpan itu halhal yang tidak baik maka akan menghasilkan hal-hal yang tidak baik juga.

Ada beberapa tahapan terbentuknya aqidah dan akhlak pada siswa SDIT Permata Hati, yaitu: 


\section{Receiving (menerima)}

Pada tahap ini guru memberikan pemahaman/ pegetahuan tentang nilai-nilai aqidah dan akhlak yang harus dimiliki. Dalam memberikan pengetahuan atau mengajarkan nilai-nilai aqidah dan akhlak, guru dapat memberikan contoh-contoh konkrit dari nilai-nilai tersebut atau memberikan pemahaman baik-buruknya, manfaat dari nilai-nilai tersebut. Nilai-nilai aqidah dan akhlak yang diajarkan siswa di SDIT harus mengacu pada SKL yang telah ditetapkan kemudian diturunkan pada indikator dan dilaksanakan dalam proses pembelajaran. Pada tahap ini siswa akan menerima stimulus-stimulus yang diberikannya secara aktif dan sensitif. Pada tahap ini aqidah dan akhlak siswa belum terbentuk melainkan baru menerima dan mencari apa-apa yang cocok baginya.

Pada tahap Receiving siswa dibekali dengan pengetahuan terkait dengan aqidah dan akhlak. Ada empat pilar menurut UNESCO dalam pendidikan, salah satunya adalah learning to know atau learning to learn. Pada proses learning to know (belajar untuk tahu) siswa akan dapat memahami dan menghayati bagaimana pengetahuan diperoleh dari fenomena yang di dapatkan di lingkungannya. Pada proses ini siswa juga dapat mengetahui nilai-nilai aqidah dan akhlak yang diberikan oleh guru. Belajar untuk mengetahui learning to know dalam prosesnya tidak sekedar mengetahui apa yang bermakna tetapi juga sekaligus mengetahui apa yang tidak bermanfaat bagi kehidupannya. Pada tahap ini siswa hanya menerima sekedar memperoleh informasi/ stimulus yang terkait dengan aqidah dan akhlak bukan terbentuknya aqidah dan akhlak siswa. Receiving (menerima) merupakan kegiatan untuk memperoleh pengetahuan tentang aqidah dan akhlak melalui dari penjelasan guru, membaca atau melihat fenomena-fenomena yang ada disekitar. Untuk itu, peran guru dalam tahap Receiving (menerima) adalah sebagai sumber belajar, fasilitator, demonstator, sebagai pembimbing, evaluator dalam memberikan tentang aqidah dan akhlak kepada siswa. Sehingga pada tahap ini aqidah dan akhlak siswa belum terbentuk melainkan baru menerima apa yang diberikan oleh guru dan mencari apa-apa yang cocok baginya.

Ada tiga tahap dalam receiving, pertama, awareness (kesiapan untuk menerima). Pada tahap ini adanya kesiapan untuk berinteraksi dengan stimulus (fenomena atau objek yang akan dipelajari) yang ditandai dengan kehadiran dan usaha untuk memberi perhatian pada stimulus yang bersangkutan. Kedua, willinginess to receive (kemauan untuk menerima), yakni usaha untuk mengalokasi perhatian pada stimulus yang bersangkutan. Ketiga, controlled or selected attention (mengkhususkan perhatian) yakni mungkin perhatian itu hanya tertuju pada warna, suara atau kata-kata tertentu saja (Zubaidi, 2012:26). Pada tiga tahap ini di SDIT Permata Hati guru memberikan pengetahuan nilai-nilai aqidah dan akhlak melalui proses pembelajaran maupun program dalam kegiatan sehari-hari yang telah diprogramkan.

\section{Responding (menanggapi)}

Responding merupakan partisipasi aktif dari siswa. Dalam proses menanggapi meliputi beberapa proses, yakni acquiescene of responding (kesiapan menanggapi), willingness to respond (kemauan menanggapi) dan satisfaction in response (kepuasan menaggapi) (Zubaidi, 2012:27). Pada tahap ini siswa mulai menangapi atau memberikan rangsangan afektif yang meliputi compliance (manut), secara aktif memberikan perhatian dan satisfication is respons (puas dalam menanggapi). Tahap ini siswa sudah mulai aktif dalam menanggapi apa yang diberikan oleh guru yang terkait dengan aqidah dan akhlak. Cara memberikan respon siswa di SDIT Permata Hati dalam menerima pengetahuan tentang aqidah dan akhlak beragam, ada yang langsung menerima atau belajar untuk melakukannya apa yang diterimanya (learning to do) dan ada yang tidak langsung melakukan apa yang diterimanya. Hal ini disebabkan karena lingkungan pergaulan mereka yang terbawa ke sekolah.

Dalam proses Responding (menanggapi) siswa akan melalui proses penilaian (valuing), yakni siswa akan menerima apa yang diajarkan oleh guru, selanjutnya siswa akan 
meyeleksi apa yang diberikan oleh guru sesuai yang disenanginya dan yang terakhir siswa akan berkomitmen melakukan dalam sebuah tindakan tentang nilai-nilai aqidah dan akhlak. Dari data yang didapat di SDIT Permata Hati, siswa akan menanggapi apa yang diberikan oleh guru, sesuai dengan perkembangan siswa dan latarbelakang siswa. Oleh sebab itu dalam meresponnya beragam ada yang langsung menerima dan langsung menjalankan ada juga yang belum bisa menerima butuh proses dalam menanggapinya. Disinilah peran guru untuk selalu menasehati, membimbing dan mengarahkan sesuai dengan aqidah dan akhlak islami.

\section{Acting (bertindak)}

Acting adalah proses proses bagaimana siswa membuat pengetahuan tengtang nilainilai aqidah dan akhlak diwujudkan dalam suatu tindakan. Acting adalah buah dari proses responding siswa. Dalam proses ini siswa diberi kesempatan untuk mengaktualisasikan nilainilai aqidah dan akhlak yang sudah diresponnya dalam kehidupanya sehari-hari. Sesuai pengamatan peneliti setelah siswa diajari tentang nilai-nilai aqidah dan akhlak dan siswa meresnponya sesuai dengan kemampuannya serta memberikan penilaian terhadap apa yang diketahui, selanjutnya siswa diminta melakukan apa yang dipelajari pada proses pembiasaan.

Dalam proses acting nilai-nilai aqidah dan akhlak, menurut pengamatan peneliti selama berada di SDIT Permata Hati, mereka dalam keseharian di sekolah melakukan hal-hal sebagai berikut (1) sholat Dhuha dan sholat Dzuhur berjama'ah tepat waktu; (2) siswa berdoa ketika sebelum dan sesudah makan; (3) siswa untuk berdoa sebelum dan sesudah belajar; (4) siswa bertutur kata yang baik, sopan santun dan lain sebagainya; (5) siswa membaca alQur'an satu hari satu ayat; (6) siswa senantiasa menerapkan 3S (salam, senyum dan sapa) dan lain sebagainya. Hasil pengamatan ini ternyata juga sejalan dengan penelitian yang dilaksanakan oleh Sholeh (2016: 148) yang menyatakan bahwa nilai-nilai pendidikan karakter seperti bertakwa kepada Allah SWT, berbakti kepada orang tua/wali, mencintai al-qur'an, berakhlak, jujur dan mencintai lingkungan sekitar dapat diwujudkan dalam kegiatan keseharian siswa. Tidak hanya di sekolah, aqidah dan akhlak yang sudah terbentuk pada siswa juga diaktualisasikan di lingkungan keluarga dan masyarakat. Siswa menjadi lebih mandiri dalam beribadah baik sholat wajib maupun sholat dhuha, bertuturkata yang baik dan lemah lembut, bisa membedakan mana yang baik dan yang buruk, terbiasa memngucapkan kalimatkalimat yang baik dan lain sebagainya.

\section{Being (menjadi seperti yang diketahui)}

Pada tahap ini siswa seharusnya sudah terbentuk aqidah dan akhlaknya atau bisa dikatakan sudah menjadi kebiasan (being). Jadi siswa secara spontan akan melakukan apa yang dipelajarinya dan apa yang dipraktekannya dalam kehidupan sehari-hari baik di lingkungan sekolah maupun di lingkungan keluarga dan masyarakat. Pada tahap ini siswa SDIT Permata Hati sudah terbiasa dengan apa yang diajarkan oleh gurunya melalui pembelajaran, pembiasaan dalam kegitan sehari-hari disekolah dan keteladanan. Hal ini terbukti beberapa orang tua siswa menyatakan bahwa anak-anaknya sering mengamalkan apa yang diajarkan gurunya disekolah, orang tua hanya mengawasi dan mengingatkan apabila perilaku tidak sesuai dengan ajaran agama Islam.

Berdasarkan penjelasan diatas dapat disimpulkan bahwa dalam pembentukannya sekolah melalui empat tahapan, yakni Receiving (menerima), Responding (menanggapi), acting (bertindak) dan being (melakukan seperti yang diketahui) dalam kehidupannya baik dilingkungan keluarga, sekolah maupun masyarakat. Hal ini sesuai empat pilar yang ditawar UNESCO dalam hal pendidikan, selain learning to know, pilar yang kedua adalah learning to do. Learning to do mengupayakan terhadap diberdayakan siswa agar mau dan mampu berbuat untuk memperkaya pengalaman belajarnya sehingga mampu menyesuaikan diri dan berpartisipasi dalam lingkungan. Johansyah berpendapat bahwa pendidikan karakter (akhlak) 
tidak hanya mengajarkan baik dan buruk saja tetapi lebih dari pada itu, pendidikan karakter (akhlak) menanamkan kebiasaan (habituation) tentang hal yang mana yang baik sehingga siswa menjadi paham (kognitif) tentang mana yang benar dan salah, mampu merasanakan (afektif) nilai yang baik dan biasa melakukannya (psikomotor). Dengan kata lain, dalam proses pembentukan aqidah dan akhlak melibatkan tiga aspek, yakni pengetahuan, merasakan dan tindakan serta dilakukan secara terus menerus sehingga menjadi habit (kebiasaan). Menurut Prochaska dan D'Clemente dalam (Zubaidi, 2012:28), menyatakan bahwa dalam perubahan perilaku terdapat lima tahap hingga perilaku itu benar-benar berubah. Pertama, precontemplation yaitu kondisi awal seseorang yang pada dasarnya manusia tidak ingin mengubah perilaku. Kedua, contemplation yaitu pertimbangan untuk berubah. Ketiga, prepation yaitu tahapan membuat sedikit perubahan. Keempat, action yaitu tahapan dimana seseorang mulai terikat pada perilaku baru. Kelima, maintenance yaitu tahapan mempertahankan perilaku baru.

\section{Faktor yang mendukung keberhasilan dalam pembentukan aqidah dan akhlak pada siswa Sekolah Dasar}

1. Guru

Guru/ pendidik adalah orang dewasa yang bertanggung jawab memberi bimbingan atau bantuan kepada siswa dalam perkembangan jasmani maupun rohaninya agar mencapai kedewasaannya, mampu melaksanankan tugasnya sebagai makhluk Allah, khalifah di muka bumi, sebagai makhluk sosial dan sebagai makhluk individu yang dapat berdiri sendiri. Guru mempunyai tugas sangat penting dalam dunia pendidikan, diantaranya adalah (a) membimbing, mencari pengetahuan terhadap kebutuhan dan kesanggupan siswa; (b) menciptakan situasi pendidikan yang konsusif, dimana seluruh tindakan pendidikan berlangsung dengan baik sehingga mencapai hasil yang memuaskan; (c) memiliki pengetahuan agama dan pengetahuan yang diperlukan untuk diamalkan dan diyakini (Arief, 2002:72).

Di SDIT Permata Hati, salah satu faktor keberhasilan dalam pembentukan aqidah dan akhlak pada siswa adalah guru. Tanpa guru, pembentukan aqidah dan akhlak pada siswa hanya menjadi slogan belaka, karena semua bentuk kebijakan dan program pada akhirnya akan ditentukan oleh peran guru. Sebagai guru ada beberapa hal yang harus dilakikan dalam pengembangan proses pembentukan aqidah dan akhlak, yakni (1) menebarkan salam; (2) melaksanankan sholat berjama'ah di Sekolah; (3) pengajian dan baca tulis Al-Qur'an; (4) kegiatan praktek ibadah; (5) kegiatan silaturahim di kalangan siswa dan guru.

Berdasarkan penjelasan diatas maka dapat disimpulkan bahwa peran guru sangat berpengaruh dalam proses pembentukan aqidah dan akhlak pada siswa. Karena perilaku guru baik perkataan maupun perbuatan guru yang senantiasa di awasi oleh siswa. Sifat siswa yang mudah meniru apa yang disenanginya, hal ini memudahkan dalam menanamkan aqidah dan akhlak kepada siswa. Oleh sebab itu guru dituntut mempunyai akhlak yang mulia. Disamping itu peran guru dalam proses pembelajaran juga berpengaruh dalam proses pembentukan aqidah dan akhlak. Guru harus mencari metode pembelajaran yang tepat dalam mengajarkan aqidah dan akhlak kepada siswa, sehingga disamping guru dituntut mempunyai akhlak yang mulia juga dituntut juga secara akademik bisa menjadi agen pembelajaran yang bisa menghantarkan siswa menuju apa yang direncanakan. Guru mempunyai andil yang sangat besar dalam dunia pendidikan, karena menghantarkan siswa menguasai suatu konsep tertentu. Sebagaimana pendapat Ahmad Fatah, menyatakan bahwa guru atau pendidik dalam suatu pendidikan perannya sangat menentukan dalam arti mempunyai peranan yang sangat besar untuk menghantarkan anak didik atau siswa menuju keberhasilan dalam pendidikan, apalagi untuk pendidikan di sekolah dasar. 


\section{Orang tua}

Orang tua adalah mempunyai peran yang cukup andil dalam pendidikan maupun pembentukan aqidah dan akhlak siswa, sebagaimana sabda Rasulullah yang artinya Rasulullah Shallallahu 'alaihi wa Salam bersabda: "Setiap anak itu dilahirkan dalam keadaan fitrah lalu kedua orang tuanyalah yang menjadikannya sebagai seorang yahudi, nasrani dan majusi(penyembah api) (H.R Muslim:4807 ).

Dari hadits tersebut dapat dipahami bahwa selain guru, orang tua juga menjadi salah satu dari faktor keberhasilan dalam proses pembentukan aqidah dan akhlak siswa. Guru mempunyai tanggung jawab terhadap siswanya di sekolah, sedangkan di lingkungan keluarga maupun sekitar orang tualah yang berperan penting. Keluarga merupakan unit kecil yang mempunyai peran strategis dalam proses pembentukan aqidah dan akhlak anak. Untuk itu harus ada kerjasama antara orang tua dan sekolah dalam proses pembentukan aqidah dan akhlak kepada siswa. Di SDIT Permata Hati, orang tua adalah mitra sekolah dalam mencapai tujuan pendidikan di SDIT. Dengan menjalin kerjasama maka guru akan banyak mendapat banyak informasi terkait karakter siswa, perkembangan siswa dirumah dan serta bisa bekerjasama dalam pengawasan siswa di lingkungan rumah. Apabila di sekolah sudah ajari, di biasakan tetapi di rumah tidak diawasi, atau tidak diingatkan maka akan menjadi kendala tersendiri di sekolah. Untuk itulah pentingnya orang tua dalam mensingkronkan programprogram sekolah dengan orang tua yang terkait dengan proses pembentukan aqidah dan akhlak pada siswa.

\section{PENUTUP}

Proses terbentuknya aqidah dan akhlak pada siswa sekolah dasar melalui empat tahap, yakni Pertama, Receiving (menerima). Pada tahab ini siswa menerima pengetahuan yang diberikan oleh guru baik melalui pembelajaran maupun secara langsung. Dalam tahap ini guru bisa menggunakan strategi pembelajaran. Dengan strategi ini guru bisa mengajarakan kepada siswa tentang materi-materi aqidah dan akhlak dengan menggunakan berbagai pendekatan atau metode pembelajaran. Selain itu guru juga bisa mengajarkan dengan strategi keteladan baik secara terprogram maupun tidak terprogram. Kedua, Responding, tahap ini adalah kelanjutan dari tahap receiving. Setelah mereka menerima apa yang diberikan guru, mereka akan meresponnya, ada yang langsung menerima ada juga yang butuh proses dalam menerima. Dalam tahap ini guru selalu memberikan penguatan-penguatan terkait materi aqidah dan akhlak, agar siswa dalam merespon dan melakukan penilian sesuai tujuan yang diinginkan. Ketiga, acting. Pada tahap ini siswa melakukan apa yang didapatkan dari proses receiving melalui responding dalam kehidupannya sehari-hari. Dalam tahap ini guru bisa menggukan strategi pembiasaan, yakni membiasakan siswa untuk mengaplikasikan pelajaran yang didapatnya dalam kegiatan sehari-hari. Guru dalam hal ini berperan sebagai fasilitator dan motivator. Kemudian yang keempat being, setelah apa yang diterima dilakukan setiap hari maka akan menjadi being atau melakukan sesuai yang diinginkan. Pada tahap ini siswa diharapkan mempunyai aqidah dan akhlak sesuai yang diharapkan, melalui pembelajaran, memberikan keteladanan dan pembiasaan yang terus menerus dan konsisten maka aqidah dan siswa akan terbentuk. Siswa mengaplikasikan nilai-nilai aqidah dan akhlak dalam kehidupannya secara spontan tanpa ada dorongan dari siapapun.

Adapun faktor pendukung keberhasilanya dalam pembentukan aqidah dan akhlak pada siswa sekolah dasar, diantaranya (1) peran seorang guru, guru sangat penting dalam proses pembentukan aqidah dan akhlak kepada siswa. Guru adalah pelaksana dari program-program yang telah dibuat di sekolah. Guru juga sebagai model/ figur bagi siswanya serta guru juga sebagai agen pembelajaran. Guru tidak hanya mengajarkan sebuah ilmu, tetapi guru adalah sebagai pembimbing, pencerah dan motivator bagi siswa. (2) Peran orang tua, karena orang tualah yang membersamai siswa dilingkungan sekitar. Orang tua sebagai pengawas dan 
penasehat siswa apabila siswa berada di lingkungan masyarakat. Untuk itu kerja sama antara guru dan orang tua sangat penting guna tercapainya sebuah tujuan yang diinginkan.

\section{DAFTAR PUSTAKA}

Adisusilo, S. (2013). Pembelajaran Nilai-nilai Karakter. Jakarta: Rajawali Press.

Ali, Z. (2017). Pendidikan Agama Islam. Jakarta: Bumi Aksara.

Alim, M. (2006). Pendidikan Agama Islam: Upaya Pembentukan Pemikiran dan Kepribadian Muslim. Bandung: Rosdakarya.

Arief, A. (2002). Pengantar Ilmu dan Metodologi Pendidikan Islam. Jakarta: Ciputra Pres.

Bungin, B. (2007). Penelitian Kualitatif: Komunikasi, Ekonomi, Kebijakan Publik dan Ilmu Sosial Lainnya. Jakarta: Kencana.

Desmita. (2010). Psikologi Perkembangan Peserta Didik. Jakarta: Remaja Rosdakarya.

Hidayat, N. (2015). Akidah Akhlak dan pembelajarannya. Yogyakarta: Ombak.

Jawas, Y. bin A. Q. (2008). Syarah Aqidah Ahlus Sunnah wal Jama'ah. Jakarta: Pustaka Imam asy-Syafi'i.

Lubis, M., \& Zubaedi. (2011). Evaluasi Penilaian Nilai. Yogyakarta: Pustaka Pelajar.

Mansur. (2005). Pendidikan Usia Dini dalam Islam. Jakarta: Pustaka Pelajar.

Nazarudin. (2007). Manajemen Pembelajaran: Implementasi dan Metodologi Pendidikan Agama Islam di Sekolah Umum. Yogyakarta: Teras.

Okezone. (2015). Kekerasan Seksual terhadap Anak di Papua Naik Tajam : Okezone News. Retrieved May 16, 2019, from https://news.okezone.com/ website: https://news.okezone.com/read/2015/07/05/340/1176456/kekerasan-seksual-terhadapanak-di-papua-naik-tajam

Papua, Kom.-R. (2015, June 23). Kota Jayapura, Anak Korban NARKOBA hingga PSK Anak ada disana. Retrieved May 16, 2019, from KOMa-RIA Papua website: https://kepugemagaijr.wordpress.com/2015/06/23/kota-jayapura-anak-korbannarkoba-hingga-psk-anak-ada-disana/

Sholeh, M. (2016). Pendidikan Karakter Melalui Implementasi Budaya Religius di Sekolah (Studi di SD LPI Zumrotus Salamah Tulungagung). Al-Adzka, Jurnal Ilmiah Pendidikan Guru Madrasah Ibtidaiyah, 6 (01), 129-150

Sugiono. (2013). Cara Mudah Menyusun Skripsi, Tesis dan Disertasi. Bandung: Alfabeta.

Sukmadinata, N. S. (2010). Metode Penelitian Pendidikan. Bandung: Remaja Rosdakarya.

Syah, M. (2014). Telaah Singkat Perkembangan Peserta Didik. Jakarta: Rajagrafindo Persada.

Yusuf, S., \& Sugandhi, N. M. (2011). Perkembangan Peserta Didik. Jakarta: Rajagrafindo Persada.

Zubaidi. (2012). Desain Pendidikan Karakter: Konspsi dan Aplikasinya dalam Lembaga Pendidikan. Jakarta: Kencana.

Kitab Sembilan Digital

Peraturan Menteri Agama Republik Indonesia nomor 912 tahun 2013 tentang Kurikulum Madrasah 2013 Mata Pelajaran Pendidikan Aagama Islam dan Bahasa Arab Bab III Standar Isi Pendidikan Agama Islam dan Bahasa Arab di Madrasah 